\title{
ANALISIS UNDANG-UNDANG NOMOR 26 TAHUN 2007 TENTANG PENATAAN RUANG UNTUK MENGATASI PERMASALAHAN PENATAAN RUANG BAGI PEMERINTAHAN DAERAH DI INDONESIA
}

\section{Dimas Dwiki Sumarsono}

Fakultas Hukum, Universitas Singaperbangsa Karawang, dimassdwiki99@gmail.com

\begin{abstract}
At present, the issue of environmental and spatial use only concerns the upper class without paying attention to AMDAL, the Regional Government as the holder of responsibility in the respective provinces and districts / cities must uphold the 1945 Constitution Article 33 paragraph (3) as a reference for the creation utilization and good spatial planning. Regional apparatuses are accountable to the Regional Head in the framework of administering governance in the regions. Regional government institutions have an important position in the Indonesian state government system. Therefore, it is necessary to know how the structure and function of these regional government institutions because as citizens we have an obligation to participate in overseeing the running of government, especially our own regional government. Moreover, at this time the regions already have autonomy so that regional government institutions have a really important position in the implementation of regional government activities. The conclusion of this article is that it is hoped that the analysis of Law Number 26 of 2007 concerning Spatial Planning can be a factor in the application of the concept of good spatial planning in every regional government in Indonesia.
\end{abstract}

\section{ARTICLE INFO}

\section{Keywords:}

Environmental Utilization;

Local Government

Authority; Local

Government Policies

\section{Cite this paper:}

Sumarsono, D. D. (2021).

$\neg$ Analisis Undang-Undang

Nomor 26 Tahun 2007

Tentang Penataan Ruang

Untuk Mengatasi

Permasalahan Penataan

Ruang Bagi Pemerintahan

Daerah Di Indonesia. Widya

Yuridika: Jurnal Hukum.

Scope Article

Environmental Law

\section{PENDAHULUAN}

Sesuai dengan Undang-undang 23 Tahun 2014 tentang Pemerintahan Daerah, pasal 1 ayat (2) bahwa pemerintahan daerah sebagai penyelenggara urusan pemerintahan oleh pemerintah daerah dan dewan perwakilan rakyat daerah menurut asas otonomi dan tugas pembantuan dengan otonomi seluas-luasnya dalam sistem dan prinsip Negara Kesatuan Republik Indonesia sebagaimana dimaksud dalam UUD Tahun 1945. Sedangkan pasal 1 ayat (3) menyatakan bahwa pemerintah daerah adalah kepala daerah sebagai unsur penyelenggara Pemerintahan Daerah yang memimpin pelaksanaan urusan pemerintahan yang menjadi kewenangan daerah otonom. ${ }^{1}$

Dari pengertian diatas dapat dinyatakan bahwa penyelenggaraan pemerintahan suatu negara akan berjalan dengan baik apabila didukung oleh lembaga-lembaga negara yang

\footnotetext{
${ }^{1}$ Undang-Undang No.23 Tahun 2004 tentang Pemerintahan Daerah Pasal 1 ayat (2 dan 3)
} 
saling berhubungan satu sama lain dalam kesatuan untuk mewujudkan nilai-nilai nasionalisme sesuai dengan kedudukan, peran, kewenangan dan tanggung jawabnya masing-masing. Negara Indonesia terbagi atas daerah-daerah provinsi yang dibagi lagi menjadi daerah kabupaten dan daerah kota. Setiap daerah provinsi, daerah kabupaten dan daerah kota memiliki lembaga pemerintahan daerah yang diatur dengan undang-undang.

Perangkat daerah ialah organisasi pada pemerintah daerah yang memiliki tanggung jawab kepada kepala daerah dalam melaksanakan tugas penyelenggaraan pemerintahan di daerah. Lembaga pemerintahan daerah mempunyai kedudukan yang penting dalam sistem pemerintahan negara Indonesia. Oleh karena itu, perlu diketahui tentang struktur dan fungsi lembaga pemerintahan daerah ini karena sebagai warga negara kita mempunyai kewajiban untuk turut serta mengikuti dan mengawasi jalannya pemerintahan, khususnya pemerintahan daerahnya. Pada suatu daerah yang sudah memiliki otonomi sehingga lembaga pemerintahan daerah memiliki posisi yang benar-benar penting dalam penyelenggaraan kegiatan pemerintahan daerah.

Cita-cita negara Indonesia dalam pengelolaan sumber daya alam terdapat di dalam Pasal 33 Ayat (3) UUD Tahun 1945 sebagai landasan konstitusional yang menyatakan bahwa bumi, air serta kekayaan alam lainnya yang terkandung di dalamnya dikuasai oleh negara dan digunakan sebesar-besarnya untuk kemakmuran rakyat. Ruang wilayah Negara Kesatuan Republik Indonesia yang merupakan negara kepulauan, baik sebagai kesatuan wadah yang meliputi ruang darat, ruang laut, dan ruang udara, termasuk di dalam bumi, maupun sebagai sumber daya, perlu ditingkatkan upaya pengelolaannya secara bijaksana, berdaya guna dan berhasil guna dan dikelola secara berkelanjutan untuk sebesar-besarnya kemakmuran rakyat.

Kota sebagai salah satu pusat perekonomian wilayah di Indonesia memiliki peran yang penting bagi pembangunan daerah, dimana konstribusinya terhadap pemenuhan kebutuhan hidup yang tidak baik pada warganya akan melahirkan berbagai permasalahan. Jumlah penduduk di Indonesia yang terus bertambah dan dikaitkan dengan implikasinya pada tata ruang kota. Apalagi ada banyak kejadian terutama di negara berkembang, kota-kota tersebut berkembang tanpa pengendalian. Jumlah penduduk yang terus bertambah tersebut berpengaruh pada ruang kota yang semakin padat dan kualitasya menjadi rendah, lalu lintas yang kacau, penghijauan sangat kurang, terjadi banjir dan sebagainya tentunya mempengaruhi kualitas hidup penduduknya.

Kegiatan pengoptimalan pemanfaatan sumber daya alam harus didasari atas keyakinan bahwa kebahagiaan hidup dapat tercapai apabila didasarkan atas keserasian, keselarasan dan keseimbangan baik dalam hidup manusia sebagai individu yang bergantung dengan individu lain, hubungan manusia dengan alam maupun hubungan manusia dengan Tuhan Yang Maha Esa. Keyakinan dapat menjadi landasan ideal dan moral yang baik dalam implementasi penataan ruang di Republik ini.

Isu tentang pemanfaatan lingkungan maupun tata ruang yang hanya mementingkan golongan atas tanpa memperhatikan AMDAL maka pemerintah daerah selaku pemegang tanggung jawab di daerah provinsi dan kabupaten/kota masing-masing harus memegang teguh UUD 1945 Pasal 33 ayat (3) sebagai acuan agar terciptanya pemanfaatan dan penataan ruang yang baik.

Banyaknya ancaman lingkungan seperti bencana banjir mengintai berbagai daerah di Indonesia seperti provinsi Kalimantan Selatan dimana notabenenya berisikan dengan hutan-hutan yang sangat luas tetapi masih saja terkena banjir yang cukup besar. Selain dikarenakan curah hujan ekstrem, tak sedikit pihak menuding penyebab banjir tersebut karena masifnya pembukaan lahan. Faktor inilah yang kemudian dianggap turut andil terciptanya banjir besar di Kalimantan. Pada rentang waktu 2009 sampai 2011, sudah terjadi peningkatan luas perkebunan sebesar 14 persen dan terus meningkat di tahun 
berikutnya sebesar 72 persen dalam 5 tahun. "Sedangkan pembukaan tambang, bukaan lahan cukup meningkat sebesar 13 persen hanya dalam kurun waktu 2 tahun. Luas bukaan tambang pada 2013 adalah 54.238 hektar, $^{2}$

Hal inilah yang melatar belakangi penulis untuk membahas mengenai betapa pentingya penerapan penataan ruang yang baik dalam pemerintahan daerah di Indonesia merujuk pada Undang-undang Nomor 26 Tahun 2007 tentang Penataan Ruang agar mengurangi berbagai permasalahan bencana alam. Di dalam makalah ini saya berharap agar pembaca mendapatkan pengetahuan mengenai lembaga pemerintahan daerah yang memiliki peran, kedudukan serta fungsi yang penting di dalam jalannya penyelenggaraan.

\section{METODE}

Metode penelitian yang digunakan di dalam penelitian ini ialah metode penelitian hukum normatif. Spesifikasi penelitian ini adalah penelitian deskriptif analitis, yaitu dengan menggambarkan fakta-fakta berupa data dengan bahan-bahan hukum primer yaitu berupa peraturan perundang-undangan bahan-bahan hukum sekunder yaitu doktrin (pendapat para ahli hukum), dan bahan-bahan hukum tersier yaitu kamus hukum atau ensiklopedia, serta bahan yang diambil dari jurnal-jurnal hukum yang berkaitan dengan permasalahan yang diangkat pada penelitian ini, untuk memperoleh gambaran yang menyeluruh dan sistematis.

Analisa dari data dalam penelitian ini dilakukan dengan metode normatif kualitatif. Normatif karena penelitian ini berfokus dari peraturan perundang-undangan yang ada sebagai hukum positif. Dapat disebut kualitatif karena merupakan analisis dan penelaahan yang mendalam, yang tidak hanya berpegang pada statistik, namun lebih menitik beratkan pada perilaku dan interaksi dari nilai-nilai dalam suatu proses realita atau fakta sosial yang terjadi dalam masyarakat.

Metode penelitian harus menguraikan metode yang digunakan dalam mengatasi masalah termasuk metode analisis. Harus berisi cukup detail yang memungkinkan pembaca untuk mengevaluasi kesesuaian metode serta reliabilitas dan validitas temuan.

\section{HASIL DAN PEMBAHASAN}

\section{Penyelenggaraan, Asas Dan Tujuan Pemerintahan Daerah Yang Ada Di Indonesia}

Sebelum membahas mengenai penyelenggaraan, asas dan tujuan dari pemerintahan daerah, lebih baik mengetahui tentang dasar atau pengertiannya dahulu. Menurut Seperti yang sudah dijelaskan pada Undang-undang Nomor 23 Tahun 2014 tentang "Pemerintahan Daerah" Pasal 1 ayat (2) bahwa pemerintahan daerah mengurusi urusan pemerintah daerah sedangkan dewan perwakilan rakyat daerah sesuai dengan otonomi daerah dan tugas pembantuan dengan prinsip otonomi yang terdapat dalam sistem dan prinsip Negara Kesatuan Republik Indonesia sebagaimana dimaksud UUD 1945”.

Setiap pemerintah daerah di Indonesia dipimpin oleh kepala daerah yang dipilih secara demokratis. Baik gubernur, bupati, dan walikota masing-masing sebagai kepala pemerintah daerah provinsi, Kabupaten dan kotanya masing-masing. Kepala daerah memiliki hak untuk dibantu oleh wakil kepala daerah, untuk provinsi disebut wakil gubernur, untuk kabupaten disebut wakil bupati dan untuk kota disebut wakil wali kota. Kepala dan wakil kepala daerah memiliki tugas, wewenang dan kewajiban serta larangan yang harus dipatuhinya. Kepala daerah juga mempunyai kewajiban untuk memberikan laporan penyelenggaraan pemerintahan daerah kepada pemerintah pusat, dan memberikan laporan keterangan

\footnotetext{
${ }^{2}$ Achmad Nasrudin, Teka-teki Penyebab Banjir Besar di Kalimantan Selatan, Diambil 21 Januari 2021, Dari https://nasional.kompas.com/read/2021/01/21/08535951/teka-teki-penyebab-banjir-besar-dikalimantan-selatan?page=all
} 
pertanggungjawaban kepada Dewan Perwakilan Rakyat Daerah (DPRD), serta memberikan informasi mengenai laporan penyelenggaraan pemerintahan daerah kepada masyarakat.

\section{A. Penyelenggaraan dan Asas Pemerintahan Daerah d Indonesia}

Sejak berdirinya Negara Republik Indonesia, para pendiri telah memilih pemilihan mereka berdasarkan prinsip pembagian tanggung jawab dalam administrasi negara. Konstitusi 1945 dikonfirmasi oleh Keputusan Presiden 5 Juli 1959. Dalam perkembangannya, sejarah menyatakan bahwa keberhasilan pemberian kewenangan berupa desentralisasi kepada daerah ini harus selalu dipertahankan oleh negara Republik Indonesia, meskipun dalam satu periode intensitas perbedaan intensitas diamati: pemerintah.

Munculnya berbagai undang-undang dan berbagai peraturan untuk pemerintah daerah menunjukkan bahwa keinginan untuk mewujudkan cita-cita mengenai penyelenggaraan pemerintahan daerah sesuai dengan UUD 1945. Terlepas dari segala hal serta kenyataan yang menunjukkan bahwa pikiran masih jauh dari kenyataan. Otonomi daerah lebih dari sekedar harapan atas pelaksanaan yang sudah berjalan selama ini. Oleh karena itu pelaksanaan pemberian kewenangan dan kebijakan kepada daerah tidak tercapai sesuai rencana. Maka sebagai pengemban tugas dari pemerintah sebaiknya lebih pemerintah daerah fokus pada otonomi daerah yang sebenarnya.

Beberapa faktor menentukan perspektif pemerintahan daerah, termasuk:

a. Faktor manusia sebagai pelaksana tugas di lapangan, peran dari masyarakat dalam pelaksanaan otonomi daerah. Faktor manusia ini harus baik dalam perihal moral dan kinerjanya, sebab mencakup unsur-unsur pemerintah daerah, termasuk pemimpin daerah dan DRPD, pemerintah keamanan swasta nasional, di mana kegiatan pemerintah daerah berlangsung.

b. Faktor keuangan yang menjadi faktor penting dalam pelaksanaan kegiatan pemerintah daerah. Ini merupakan salah satu karakterstik daaerah otonom dalam mengembangkan kemampuannya dalam menghasilkan dana untuk menunjang pembangunan daerah tersebut. Oleh karena itu, kapasitas menghasilkan dana dari sektor mandiri daerah cukup mempengaruhi pelaksanaan roda pemerintahan daerah. Penghasilan pemerintah daerah biasanya berasal dari pajak dan bea daerah, layanan lokal dan regional dan produk regional lainnya yang sah harus dapat berkontribusi pada pendanaan keuangan daerah.

c. Faktor peralatan dan perlengkapan menjadi struktur pendukung untuk menjalankan kegiatan pemerintah daerah. Peralatan yang ada harus memenuhi standar dalam hal kuantitas, kualitas, dan penggunaan praktis. Kondisi untuk jenis peralatan ini akan berdampak signifikan pada pemerintah daerah.

d. Organisasi manajemen pemerintahan yang profesional diberikan kepada sumber daya manusia yang berintegritas tinggi, agar pelaksanaan pemerintahan daerah dapat berjalan dengan maksimal.

Keterlibatan ke empat faktor diatas saling berkaitan dan berhubungan dalam menjalankan sistem pemerintahan di daerah agar tercapai cita-cita dan tujuan dari otonomi didaerah. Program yang dibuat oleh pemerintah pusat merupakan program dan kebijakan yang harus dilaksanakan penyelenggaraannya oleh daerah, melalui lembaga-lembaga agar pembangunan kesejahteraan masyarakat di daerah terpencil yang tidak terjangkau dalam jangkauan pemerintah pusat dapat menikmati pemerataan pembangunan dan kesejahteraan. Dalam melaksanakan kebijakan ini, pemerintah daerah diberikan 
keleluasaan dalam membuat kebijakan sesuai dengan kewenangannya berdasarkan prinsip kebersamaan. ${ }^{3}$

Dalam melaksanakan kewenangannya, pemerintah daerah memiliki kewenangan untuk membuat perda-perda (zelfwetgeving) dan penyelenggaraan pemerintahan (zelfbestuur). Pelimpahan wewenang dari pemerintah pusat kepada daerah-daerah otonom bukan dikarenakan suatu hal ditetapkan dalam konstitusinya, melainkan disebabkan oleh adanya hakikat negara kesatuan itu sendiri. Prinsip dari negara kesatuan adalah bahwa yang memegang tugu kekuasaan tertinggi atas segenap urusan negara adalah pemerintah pusat (central government), tanpa gangguan oleh suatu delegasi atau penyerahan kekuasaan kepada pemerintah daerah (local government). ${ }^{4}$

Dalam hal penyelenggaraan pemerintah daerah selain membuat peraturan-peraturan daerah, pemerintah daerah pula harus menegakkan hukum agar terciptanya kepastian hukum, kemanfaatan dan keadilan. Menurut Satjipto Rahardjo penegakan hukum adalah suatu upaya untuk mewujudkan ide-ide tentang keadilan, kepastian hukum dan kemanfaatan sosial menjadi kenyataan. Proses perwujudan idee-ide tersebut merupakan hakikat dari penegakan hukum. ${ }^{5}$

Kekuasaan pemerintah pusat tidak terganggu dengan adanya kewenangan pada daerah otonom yang diberikan otonomi yang luas dan tidak bermakna untuk mengurangi kekuasaan pemerintah pusat. Pemberian sebagian kewenangan (kekuasaan) kepada daerah berdasarkan hak otonomi (negara kesatuan dengan sistem desentralisasi), tetapi pada tahap akhir, kekuasaan tertinggi tetap di tangan pemerintah pusat. Jadi, kewenangan yang melekat pada daerah tidaklah berarti bahwa pemerintah daerah itu berdaulat sebab pengawasan dan kekuasaan tertinggi masih tetap terletak di tangan pemerintah pusat. Hubungan pusat dengan daerah di mana suatu negara kesatuan yang gedecentraliseerd, pemerintahan pusat membentuk daerah-daerah, serta menyerahkan sebagian dari kewenangannya kepada daerah. 6

Menurut Hinca Pandjaitan dalam artikel Fungsi dan Akibat Hukum Keputusan Kepala Daerah Dalam Melaksanakan Urusan Tugas Pembantuan Dikaitkan dengan Pokok Pangkal Sengketa \halaman 387 , menyatakan bahwa sebagai salah satu realisasi Pasal 18 UndangUndang Dasar 1945 ("UUD 1945") serta Pasal 1 UUD 1945, pemerintah di daerah dilaksanakan melalui 3 asas, yaitu asas desentralisasi, asas dekonsentralisasi (dekonsentrasi) dan asas tugas pembantuan.

a. Desentralisasi ialah penyerahan Urusan dari Pemerintahan oleh Pemerintah Pusat kepada daerah otonom berdasarkan Asas Otonomi.

b. Dekonsentrasi ialah pelimpahan atau penyerahan sebagian Urusan Pemerintahan yang menjadi kewenangan Pemerintah Pusat kepada gubernur sebagai wakil Pemerintah Pusat, kepada instansi vertikal di wilayah tertentu, dan/atau kepada gubernur serta bupati dan wali kota sebagai bentuk tanggung jawab dalam urusan pemerintahan umum.

c. Tugas pembantuan ialah penugasan dari pemerintah pusat kepada daerah otonom untuk menjalankan sebagian urusan pemerintahan yang menjadi kewenangan pemerintah pusat atau dari pemerintah daerah provinsi kepada daerah

\footnotetext{
${ }^{3}$ Haryanti Amelia, Sistem Pemerintahan Daerah Tangerang Selatan : UNPAM Press. 11 Juli 2019 hlm. 42-43

${ }^{4}$ Agus Salim, Pemerintahan Daerah Kajian Politik dan Hukum, Ghalia Indonesia, Jakarta, 2004, hal. 27.

${ }^{5}$ Muhamad Erwin, Pendidikan Kewarganegaraan Republik Indonesia, Bandung: PT Refika Aditama. 2017, Hlm. 155

${ }^{6}$ Michael Barama, "Pelaksanaan Pemerintahan Daerah Dan Penerapan Sanksi Administrasi Dalam Peraturan Daerah". Jurnal Hukum Unsrat. Vol.22 No.5 Januari 2016, hlm. 29-30.
} 
kabupaten/kota untuk menjalankan sebagian urusannya yang menjadi kewenangan daerah provinsi. ${ }^{7}$

Dalam menjalankan tugas dan fungsinya sebagai penyelenggara pemerintahan, pemerintah daerah harus berpedoman pada asas-asas penyelenggaraan pemerintahan daerah yang diatur pada Pasal 58 Undang- Undang Nomor 23 Tahun 2014 Tentang Pemerintahan Daerah, yang terdiri atas :

1. Kepastian hukum

2. Tertib penyelenggara negara

3. Kepentingan umum

4. Keterbukaan

5. Proporsionalitas

6. Profesionalitas

7. Akuntabilitas

8. Efisiensi

9. Efektivitas

10. Keadilan. ${ }^{8}$

Berdasarkan penjelasan pada Pasal 58 Undang-Undang Nomor 23 Tahun 2014 tentang Pemerintahan Daerah, dijelaskan bahwa asas umum penyelenggaraan negara dalam ketentuan ini yang apabila digabungkan dengan Undang- Undang Nomor 28 Tahun 1999 tentang Penyelenggaraan Negara yang bersih dari Kolusi,Korupsi, dan Nepotisme (KKN), ditambah asas efisiensi dan efektivitas maka akan menjadi sebagai berikut :

a. Asas kepastian hukum : asas yang mengutamakan landasan peraturan perundangundangan, kepatutan, dan keadilan dalam setiap kebijakan penyelenggara negara.

b. Asas tertib penyelenggaraan negara : asas yang menjadi landasan keteraturan, keserasian, dan keseimbangan dalam pengendalian penyelenggara negara.

c. Asas kepentingan umum : asas yang mementingkan kesejahteraan umum dengan cara yang aspiratif, akomodatif, dan selektif.

d. Asas keterbukaan : asas keterbukaan terhadap hak masyarakat untuk memproleh informasi yang benar, jujur, dan tidak diskriminatif tentang penyelenggaraan negara dengan selalu memperhatikan perlindungan atas hak asasi pribadi, golongan, dan rahasia negara.

e. Asas proporsional : asas yang mengutamakan keseimbangan antara hak dan kewajiban penyelenggara negara.

f. Asas profesionalitas : asas yang mengutamakan keahlian yang berlandaskan dari kode etik dan ketentuan peraturan perundang-undangan yang sedang berlaku.

g. Asas akuntabilitas : asas yang menentukan setiap kegiatan dan hasil akhir dari kegiatan penyelenggara negara haruslah dipertanggungjawabkan kepada masyarakat atau rakyat.

\section{B. Tujuan Pemerintahan Daerah di Indonesia}

Dari beberapa pasal-pasal yang terkandung dalam UU No 23 Tahun 2014 maupun dalam PP No 13 Tahun 2019 tak ditemukannya tujuan penyerahan Urusan Konkuren (tujuan penyelenggaraan pemerintahan daerah) itu. Ternyata tujuan penyelenggaraan pemerintahan daerah dirumuskan dalam bagian "Menimbang" (konsideran) UU No 23 Tahun 2014.

\footnotetext{
7 Sovia Hasanah, Arti dan Maksud Tugas Pembantuan Pemerintah, Ditulis 6 Maret 2017, Dari https://www.hukumonline.com/klinik/detail/ulasan/lt58b4dd94d9b04/arti-dan-maksud-tugaspembantuan-pemerintah/

${ }^{8}$ Undang-Undang No.23 Tahun 2004 tentang Pemerintahan Daerah Pasal 58
} 
Bila diringkas terdapat dua tujuan penyelenggaraan pemerintahan daerah, yaitu :

a. Mempercepat dalam mewujudkan kesejahteraan masyarakat melalui peningkatan pelayanan, pemberdayaan, peran serta masyarakat, dan peningkatan daya saing daerah; dan

b. Meningkatkan daya efisien dan efektivitas penyelenggaraan pemerintahan daerah dalam menjalankan tugasnya.

Dari kedua tujuan ini disertai sejumlah rambu yang harus diperhatikan dalam mencapainya. Dalam mencapai tujuan pertama haruslajh memperhatikan prinsip demokrasi, pemerataan, keadilan, dan kekhasan suatu daerah dalam NKRI.

Tujuan kedua harus dicapai dengan cara memperhatikan aspek-aspek hubungan antara pemerintah pusat dengan daerah, potensi daerah, berbagai keanekaragaman daerah, serta peluang dan tantangan persaingan global dalam mewujudkan kesatuan sistem penyelenggaraan pemerintahan negara. Tujuan-tujuan diatas dalam penyelenggaraan pemerintahan daerah itu dapat diukur secara kualitatif dan kuantitatif. Pemerintah, khususnya kementerian dalam negeri harus berkoordinasi dengan kementerian teknis, seharusnya sudah menjabarkan kedua tujuan itu dalam bentuk indikator capaian.

Cita-cita dalam mewujudkan kesejahteraan rakyat akan dapat dicapai dengan cepat melalui peningkatan pelayanan publik yang berkualitas, merata, dan terjangkau. Upaya pemberdayaan sumber daya manusia sesuai dengan karakteristik ekonomi mereka, peningkatan peran serta masyarakat dalam proses pembuatan dan pelaksanaan kebijakan publik daerah dan peningkatan daya asing daerah.

Karena jarak antara pembuat kebijakan dengan masyarakat sebagai sasaran kebijakan sangat dekat, maka peran masyarakat dalam andil proses pembuatan dan pelaksanaan kebijakan akan lebih mudah. Karena jarak antara yang melayani dengan warga masyarakat yang dilayani sangat dekat, maka pelayanan publik akan dapat diberikan sesuai dengan harapan masyarakat.

Pembinaan yang seharusnya dilakukan pemerintah terhadap daerah otonom adalah membantu dan mengarahkan daerah otonom mewujudkan kedua tujuan penyelenggaraan pemerintahan daerah itu. UU No 23 Tahun 2014 menguraikan secara panjang lebar pelayanan publik yang harus dilakukan, termasuk mengeluarkan Maklumat Informasi mengenai Pelayanan Publik.

\section{Penerapan Undang-Undang Nomor 26 Tahun 2007 Tentang "Penataan Ruang" Dalam Pemerintahan Daerah di Indonesia}

Penerapan Undang-Undang Nomor 26 Tahun 2007 Tentang Penataan Ruang dapat tercapai sejalan dengan tujuan pemerintahan negara Indonesia pada umumnya terdapat dalam pembukaan UUD 1945 setelah amandemen adalah melindungi segenap bangsa Indonesia serta meningkatkan kesejahteraan umum, mencerdaskan kehidupan bangsa, serta ikut melaksanakan ketertiban dunia yang berdasarkan kemerdekaan, perdamaian abadi dan keadilan sosial.

Setelah dilakukannya pemberlakuan Undang-Undang Nomor 23 Tahun 2014 tentang Pemerintahan Daerah terhadap penyelenggaraan penataan ruang, urusan pemerintahan pusat merupakan kewenangan dari presiden yang dalam bentuk pelaksanaannya dapat diwakilkan kepada menteri yang mengurusi bidangnya dalam pemerintahan, serta kepala daerah sebagai wakil pemerintah pusat di daerah. Diberlakukannya UU Pemda mampu memberikan perubahan terhadap pembagian kewenangan dari penyelenggaraan penataan ruang dan berimplikasi terhadap implementasi kebijakan sektoral setiap daerah di Indonesia. 
Kegiatan penataan ruang di Indonesia dibagi menjadi 3 kegiatan yang saling terkait antara satu dengan yang lain, yakni perencanaan tata ruang, pemanfaatan tata ruang dan pengendalian pemanfaatan ruang dapat melalui produk rencana tata ruang berupa Rencana Tata Ruang Wilayah (RTRW) yang secara hieratki terdiri dari :
a. Rencana Tata Ruang Wilayah Nasional (RTRWN)
b. Rencana Tata Ruang Wilayah Provinsi (RTRWP) dan
c. Rencana Tata Ruang Wilayah Kabupaten/Kota (RTRW Kab/Kota).

Sebagai UU utama (core) dalam melaksanakan penyelenggaraan penataan ruang, maka UU Penataan Ruang ini diharapkan dapat mewujudkan rencana tata ruang yang mampu mengoptimalisasikan dan memadukan berbagai kegiatan sektor pembangunan, baik dalam pemanfaatan sumber daya alam maupun sumber daya buatan. ${ }^{9}$

Implikasi dari pemberlakuan UU Pemda terhadap penyelenggaraan penataan ruang lainnya adalah proses evaluasi terhadap Rancangan Perda Rencana Tata Ruang provinsi / kabupaten / kota yang menjadi lebih diperpanjang karena dalam proses evaluasi, menteri dalam negeri harus berkoordinasi dan berkolaborasi dengan Menteri Agraria dan Tata Ruang. Disamping itu, rancangan, "Kajian Terhadap Perlindungan Dan Pengelolaan Lingkungan Hidup Dalam Tata Ruang Perda Rencana Tata Ruang Kabupaten/Kota” yang sebelumnya cukup dievaluasi oleh gubernur, harus dikonsultasikan terlebih dahulu dengan menteri dalam negeri. Hal ini diperlukan tindak lanjut penyesuaian terhadap Permendagri Nomor 28 Tahun 2008 tentang Tata Cara Evaluasi Rancangan Peraturan Daerah Tentang Rencana Tata Ruang Daerah. ${ }^{10}$

Dalam konteks Undang-undang Penataan Ruang diyakini sebagai pendekatan yang tepat dalam mewujudkan keterpaduan pengelolaan sumber daya alam dan sumber daya buatan secara berdaya guna dan berhasil guna. Diharapkan dengan berpedoman pada kaidah penataan ruang, kualitas ruang wilayah nasional dapat terjaga keberlanjutannya demi terwujudnya kesejahteraan umum dan keadilan sosial.

Penerapan Undang-undang Nomor 26 Tahun 2007 tentang Penataan ruang sangat penting dalam pemerintahan daerah agar terwujudnya penataan ruang yang terpadu dan kemanfaatan untuk setiap daerah yang ada di Indonesia. Menurut penulis faktor-faktor yang harus di perhatikan oleh setiap kepala daerah yang ada di Indonesia merujuk pada undangundang tentang penataan ruang yaitu :

a. Pasal 7 : mengenai tugas dan wewenang untuk dijalankan pemerintah daerah sebagai bentuk pelimpahan tugas dari pemerintah pusat tanpa mengesampingkan hak warganya untuk memberikan solusi pada tugas pemerintah daerah.

b. Pasal 10 : mengenai wewenang pemerintah daerah provinsi untuk menyebarluaskan informasi dalam menyelengarakan penataan ruang yang harus dilakukan secara strategis sesuai dengan peraturan perundang-undangan.

c. Pasal 11 : mengenai wewenang pemerintah daerah provinsi untuk menyebarluaskan informasi dalam menyelenggrakan penataan ruang yang harus dilakukan secara strategis sesuai dengan peraturan perundang-undangan. Pasal 13 : mengenai pemerdayaan dan pembinaan pemerintah daerah provinsi dan kabupaten / kota untuk melakukan pembinaan penataan ruang melalui penelitian, pengembangan, sistem dan informasi.

\footnotetext{
9 I Wayan Parsa, dkk, Laporan Akhir Tim Pengkajian Hukum tentang Penegakan Hukum Penataan Ruang Dalam Kerangka Otonomi Daerah, Badan Pembinaan Hukum Nasional, Tahun 2014, hlm 4.

10 Dahfid Ari, "Kewenangan Pemerintah Daerah dalam Penataan Ruang Setelah Berlakunya UU No.23 Tahun 2014". Jurnal Hukum Maranatha Christian University. Vol.9 No.1, November 2017, hal.2-3.
} 
d. Pasal 35 : mengenai pengendalian pemanfaatan ruang melalui penatapan zonasi dan pemberian izin.

e. Pasal 36 : mengenai pembagian zonasi pemerintahan pusat, provinsi dan kabupaten / kota.

f. Pasal 37 : mengenai ketentuan perizinan dalam pemanfaatan ruang sesuai dengan prosedur hukum yang berlaku agar tidak merugikan manusia dan lingkungan.

g. Pasal 55 : mengenai pengawasan penataan ruang guna mencapai tujuan dan citacita tercapainya pemanfaatan ruang yang baik yang harus dilakukan oleh pemerintah provinsi dan kabupaten / kota dengan melibatkan peran masyarakat untuk mewujudkannya. 11

Dari berbagai pasal yang telah disebutkan diatas penulis berharap agar penerapan undang-undang tentang penataan ruang tersebut khhususnya pasal-pasal yang telah disebutkan dan penelitian diatas dapat diaplikasikan kepada sistem pemerintahan daerah masing-masing daerah yang ada di Indonesia agar dapat mewujudkan tujuan pemerintahan daerah yang menjalankan asas-asasnya dengan baik.

\section{PENUTUP}

Pada dasarnya setiap pemerintah daerah di Indonesia dipimpin oleh kepala daerah yang dipilih secara demokratis. Kepala Pemerintah Daerah Provinsi, Kabupaten dan Kota dibantu oleh satu orang wakil kepala daerah, untuk provinsi disebut wakil Gubernur, untuk kabupaten disebut wakil bupati dan untuk kota disebut wakil wali kota.

Implikasi dari pemberlakuan Undang-Undang No.23 Tahun 2014 tentang Pemerintahan daerah terhadap penyelenggaraan penataan ruang lainnya adalah proses evaluasi Rancangan Perda Rencana Tata Ruang Provinsi/Kabupaten/Kota yang menjadi lebih panjang karena dalam proses evaluasi, Menteri Dalam Negeri harus berkoordinasi dengan Menteri Agraria dan Tata Ruang. Dan begitu pula sebaliknya penerapan Undangundang Nomor 26 Tahun 2007 tentang Penataan ruang sangat penting dalam pemerintahan daerah agar terwujudnya penataan ruang yang terpadu dan kemanfaatan untuk setiap daerah yang ada di Indonesia

Dari beberapa pasal-pasal yang telah dijelaskan diatas mengenai Undang-Undang Nomor 26 Tahun 2007 tentang Penataan Ruang yang dapat disimpulkan bahwa penataan ruang yang baik pada pemerintahan daerah dapat diwujudkan apabila pemerintahan daerah mengikuti konstitusi yang ada dan masyarakat diijinkan berperan aktif dalam upaya penataan ruang di dalam pemerintahan daerah.

\section{DAFTAR PUSTAKA}

\section{Peraturan Perundang-undangan}

Undang-Undang Nomor 23 Tahun 2004 Tentang Pemerintahan Daerah

Undang-Undang Nomor 26 Tahun 2007 Tentang Penataan Ruang

\section{Buku}

Erwin, Muhamad Pendidikan Kewarganegaraan Republik Indonesia, Bandung: PT Refika Aditama. 2017

Salim, Agus, Pemerintahan Daerah Kajian Politik dan Hukum, Ghalia Indonesia, Jakarta, 2004

\section{Artikel Jurnal}

11 Undang-undang Nomor 26 Tahun 2007 Tentang Penataan Ruang Pasal 7,10,11,13,35,36,37 dan 55 
Dahfid Ari, "Kewenangan Pemerintah Daerah dalam Penataan Ruang Setelah Berlakunya UU No.23 Tahun 2014". Jurnal Hukum Maranatha Christian University. Vol.9 No.1, November 2017

Haryanti Amelia, Sistem Pemerintahan Daerah Tangerang Selatan : UNPAM Press. 11 Juli 2019

I Wayan Parsa, dkk, Laporan Akhir Tim Pengkajian Hukum tentang Penegakan Hukum Penataan Ruang Dalam Kerangka Otonomi Daerah, Badan Pembinaan Hukum Nasional, Tahun 2014.

Michael Barama, "Pelaksanaan Pemerintahan Daerah Dan Penerapan Sanksi Administrasi Website Dalam Peraturan Daerah". Jurnal Hukum Unsrat. Vol.22 No.5 Januari 2016

Achmad Nasrudin, Teka-teki Penyebab Banjir Besar di Kalimantan Selatan, Diambil21Januari2021,Darihttps://nasional.kompas.com/read/2021/01/21/085359 51/teka-teki-penyebab-banjir-besar-di-kalimantan-selatan?page=all

Sovia Hasanah, Arti dan Maksud Tugas Pembantuan Pemerintah, Ditulis 6 Maret 2017, Dari https://www.hukumonline.com/klinik/detail/ulasan/lt58b4dd94d9b04/arti-danmaksud-tugas-pembantuan-pemerintah/ 